\title{
DASAR KARAKTERISTIK KEPEMIMPINAN PENDIDIKAN ISLAM
}

\author{
Hikmat Kamal \\ Hikmatkamal70@gmail.com \\ (Dosen Fakultas Agama Islam, Universitas Muhammadiyah Tangerang)
}

\begin{abstract}
Abstrak:
Kepemimpinan diperlukan memiliki teladan yang menjadi model ideal pemimpin, Rasulullah SAW dikaruniai empat sifat utama, yaitu: Sidiq berarti jujur dalam perkataan dan perbuatan, Amanah berarti dapat dipercaya dalam menjaga tanggung jawab, Tablig berarti menyampaikan segala macam kebaikan kepada rakyatnya dan Fathonah berarti cerdas dalam mengelola. Agar tujuan pendidikan Islam bisa dicapai sesuai dengan yang diharapkan maka diperlukan adanya kepemimpinan yang mampu membuat perencanaan yang baik, mengorganisir, menggerakkan, dan melakukan kontrol serta mengetahui kekuatan, kelemahan, peluang, dan ancaman. Islam memberikan dasar-dasar normatif dan filosofis tentang kepemimpinan yang bersifat komprehensip dan universal. Tidak hanya untuk umat Islam tapi juga untuk seluruh umat manusia.
\end{abstract}

\section{Kata Kunci: Karakteristik, Kepemimpinan, Pendidikan Islam.}

\section{A. Pendahuluan}

Kepemimpinan sebagai suatu proses untuk menggerakkan sekelompok orang menuju suatu tujuan yang telah di sepakati berasama dengan mendorong atau memotivasi mereka untuk bertindak dengan tidak terpaksa. Dengan kemampuan seorang pemimpin yang baik dapat menggerakkan orang-orang menuju tujuan jangka panjang dan betul-betul merupakan usaha untuk memenuhi kepentingan mereka. ${ }^{1}$

Pemimpin yang dapat melaksanakan tugas kepemimpinannya secara efektif dapat menggerakkan orang atau bawahannya ke arah tujuan yang diinginkannya, dan akan menjadi anutan dan teladan. Begitu pula sebaliknya, pemimpin yang keberadaannya hanya sebagai figur dan tidak memiliki pengaruh serta kemampuan kepemimpinan, akan mengakibatkan kinerja organisasi tersebut menjadi lambat. Karena pemimpin tersebut

\footnotetext{
${ }^{1}$ Veithza Rivai, Kiat Memimpin Abad 21, (Jakarta: PT Raja Grafindo, 2004). h. 64
}

tidak memiliki kapabilitas dan kecakapan untuk menghasilkan kinerja yang baik.

$$
\text { Kepala sekolah bertugas }
$$
melaksanakan fungsi kepemimpinan, baik fungsi yang berhubungan dengan pencapaian tujuan pendidikan maupun penciptaan iklim sekolah yang kondusif bagi terlaksananya proses belajar mengajar secara efektif dan efisien. Pengaruh seorang pemimpin sangatlah menentukan keberhasilan lembaga pendidikan Islam tersebut. Kepala sekolah yang berhasil dalam memimpin, jika ia dapat memahami keberadaan sekolah sebagai organisasi yang kompleks dan unik, dan mampu melaksanakan peranan kepala sekolah sebagai seorang yang diberi tanggung jawab untuk memimpin sekolah.

Impian dan harapan besar terhadap pemimpin, mengantarkan betapa penting dan berartinya peran seorang pemimpin dalam mendesain sebuah masyarakat, bangsa dan negara. Sejarah membuktikan, kejayaan dan keemasan sebuah bangsa sangat ditentukan oleh kualitas dan kapasitas para pemimpinnya, sehingga seorang pemeimpin haruslah memiliki 
dasar dan karakteristik dalam menjalankan kepemimpinannya.

\section{B. Karakteristik \\ Pendidikan Islam}

Kepemimpinan

Semua hal yang berkaitan dengan kehidupan manusia, maupun keberadaan alam ini sudah termaktub dalam AlQur'an, termasuk asal usul penciptaan alam semesta beserta isinya, asal kejadian manusia hingga akhirnya, serta sampai pada aktivitas individu baik saat berinteraksi dengan sesama, dengan alam dan lingkungannya hingga memimpin dan mengelola berbagai jenis organisasi termasuk tentunya memenej pendidikan. Manajemen sendiri oleh Nawawi diartikan sebagai kegiatan yang dilakukan oleh manajer dalam memanage organisasi, lembaga, maupun perusahaan. ${ }^{2}$

Wahjosumidjo menyatakan secara sederhana kepala sekolah/madrasah dapat didefinisikan sebagai seorang tenaga fungsional guru yang diberi tugas untuk memimpin suatu sekolah dimana diselenggarakan proses belajar, mengajar atau tempat dimana terjadi interaksi antara guru yang memberi pelajaran dan murid yang menerima pelajaran. ${ }^{3}$

Sudarwan Danim, menyebut kepala sekolah sebagai the key person penanggung jawab utama atau faktor kunci untuk membawa sekolah menjadi center of excellence, pusat keunggulan dalam mencetak dan mengembangkan sumber daya manusia (SDM) sekolah. Sekolah menjadi efektif, sukses, atau sebaliknya, tergantung peran kepala sekolah. ${ }^{4}$

\footnotetext{
${ }^{2}$ Hadari Nawawi. Administrasi Pendidikan (Jakarta: CV. Haji Mas Agung), 1997. h. 78.

${ }^{3}$ Wahjosumidjo. Kepemimpinan Kepala Sekolah, (Jakarta: Grafindo Persada), 1999. h. 82.

${ }^{4}$ Sudarwan Danim. Visi Baru Manajemen, Jakarta: Bumi Aksara, 2005, h. 96.
}

Hal ini menunjukkan bahwa seorang kepala sekolah memiliki peran yang begitu besar di dalam meraih cita-cita (visi, misi dan tujuan) sekolah. Ini berarti profesionalisme seorang kepala sekolah menjadi sebuah keharusan. Dengan ini dapat diketahui bahwa peran seorang kepala sekolah sangatlah prinsipil. Bagaimana seorang kepala sekolah mampu mengolah dunia pendidikan dengan memberikan dorongan/dukungan semangat kepada para murid dan juga para guru. Secara operasional, kepala sekolah adalah orang yang paling bertanggung jawab dalam mengkoordinasikan, menggerakkan dan menyelaraskan semua sumber daya (resources) sekolah yang dipimpinnya. Kepemimpinan kepala sekolah merupakan faktor pendorong untuk mewujudkan visi, misi, tujuan dan sasaran madrasah yang dipimpinnya menuju madrasah yang bermutu dan berkualitas. Bermutu dalam bidang pelayanan publik, di bidang pembelajaran, sarana prasarana, pengembangan SDM, baik di bidang prestasi akademik maupun non akademik. Jadi sebagai kepala sekolah merupakan tugas utama dan mulia karena di dalamnya ada tugas suci untuk menjadikan manusia yang bermutu/berkualitas, baik dari sisi fisik maupun non fisik. Menciptakan sekolah yang bermutu, melahirkan generasi yang berkualitas, mencetak generasi yang mumpuni merupakan tugas suci lain dari seorang kepala sekolah.

Pemimpin yang professional menurut Sudarwan Danim adalah seorang "seniman" dalam memimpin. Dengan seni memimpin, dapat membedakan kepemimpinan setiap orang. Seni memimpin dilakukan dalam bentuk gaya memimpin, teknik memimpin dan cara atau kiat memimpin. Setiap orang memiliki seni memimpin sendiri-sendiri. ${ }^{5}$ Tetapi

${ }^{5}$ Sudarwan Danim. Visi Baru Manajemen, Jakarta: Bumi Aksara 2005.h. 98 
untuk keterampilan umum yang dibutuhkan seorang pemimpin pada dasarnya sama. Menurut Robert L. Katz dalam Sudarwan Danim, mengemukakan tiga jenis keterampilan yang harus dimiliki oleh seorang kepala sekolah, yakni:

1. Technical skill (keterampilan teknis), yaitu: keterampilan menerapkan pengetahuan teoritis ke dalam tindakan praktis, kemampuan memecahkan masalah dan kemampuan menyelesaikan tugas secara sistematis dan teknik-teknik dalam menyelesaikan tugas-tugas tertentu

2. Human relation skill (ketrampilan hubungan dengan manusia), yakni ketrampilan menjalin komunikasi dengan menciptakan kepuasan dengan para guru dan pegawai, bersikap terbuka/transparan, ramah tamah, menghargai dan memotivasi para guru, pegawai, siswa dan orang tua untuk kemajuan sekolah

3. Conceptual skill (ketrampilan konseptual), yakni ketrampilan memformulasikan pikiran, memahami konsep dan teori serta mampu mengaplikasikannya ke dalam pekerjaan sehari-hari, menyusun planning, budgeting, organizing, staffing, actuating, coordinating, communicating, controlling, evaluating and reporting dan mengembangkan sikap kesejawatan yang akrab dengan seluruh civitas sekolah. Untuk memungkinkan tercapainya tujuan pendidikan di sekolah, kepala sekolah bukan hanya melakukan fungsi sebagai manajer dan leader saja tetapi ada peran-peran lainnya yang harus dijalani dan melekat dengan kepala sekolah dalam tugas operasional sehari-hari. Mulyasa menuliskan tujuh peran kepala sekolah yang harus diamalkan dalam bentuk tindakan nyata di sekolah yang disingkat dengan "EMASLIM", yaitu peran sebagai Educator,
Manager, Administrator, Supervisor, Leader, Innovator, and Motivator. ${ }^{6}$

Dari uraian di atas dapat diketahui bahwa yang dimaksud dengan kepala sekolah adalah bukan sekedar leader ataupun manajer saja, tetapi kecakapan seorang pemimpin di sekolah dalam memimpin, mengatur, merencanakan, mengawasi, mendidik/membina, mengevaluasi, memupuk semangat guru dan pegawai demi tercapinya visi, misi, tujuan dan sasaran pendidikan di madrasah yang dipimpinnya. Tantangan bagi seorang kepala sekolah adalah bagaimana menjadi pendorong atau pelopor perubahan kelembagaan sekolah yang dipimpinnya. ${ }^{7}$

Bahwa pengembangan organisasi dan produktivitasnya dicapai dari buah kepemimpinan yang efektif. Hal itu akan menghasilkan mutu secara berkelanjutan dalam lembaga pendidikan. Kepemimpinan kepala sekolah dalam sistem pendidikan sangatlah penting dalam mengejar mutu yang menjadi harapan kelembagaan pendidikan sekarang ini. Tentu saja kelembagaan pendidikan hanya akan maju bila dipimpin oleh mereka yang visioner, memiliki keterampilan manajerial, serta integritas kepribadian dalam melakukan tugasnya dengan niatan ibadah kepada-Nya.

Setiap kepala sekolah harus berkeinginan untuk mengarahkan organisasinya ke dalam paradigma baru yang penuh ketidak pastian sehingga memerlukan ketekunan dan keikhlasan untuk mengelola perubahan-perubahan yang begitu cepat. Namun tentu saja untuk mencapai kondisi ini, seorang kepala sekolah tidak seyogyanya hanya mampu berperan selaku atasan yang keinginan dan

${ }^{6}$ E. Mulyasa. Manajemen Berbasis Sekolah Konsep, Strategi dan Implementasi, Bandung: Remaja Rosda Karya, 2004.h. 97.

${ }^{7}$ Sutopo Hadiyat dan Wasty, Kepemimpinan yang afektif Yogyakarta: Gajah Mada University 1998 h. 217. 
kemauannya harus diikuti orang lain. Tentunya seorang kepala sekolah yang diberi kepercayaan untuk menjadi seorang pemimpin formal dalam kelembagaan pendidikan, haruslah selalu berusaha agar kepemimpinannya disertai akseptabilitas di lingkungan bawahan, sehingga dapat dirasakan dorongan jiwa dan semangat kerjasama dalam iklim yang demokratis dan kondusif.

Ada beberapa kompetensi yang dituntut untuk dimiliki oleh setiap kepala sekolah sebagai pimpinan pendidikan yang diharapkan dapat mencapai keberhasilan sekaligus sebagai jawaban dalam membangun standarisasi pendidikan nasional di era global. Garis besar catatan penting yang disampaikan oleh Hoy dalam Syafaruddin terkait dengan daftar sejumlah kompetensi yang diperlukan dalam penerapan manajemen mutu terpadu untuk pemimpin pendidikan termasuk kepala sekolah adalah sebagai berikut: ${ }^{8}$

1. Visioner.yang dimaksud dengan

Visioner, adalah kemampuan dalam:

a. mengajukan tujuan dan sasaran sesuai keinginan sekolah;

b. melaksanakan kebutuhan sementara dalam situasi tertentu;

c. memprediksi kebutuhan sesuai tugas;

d. menghasilkan keaslian, mengungkapkan imajinasi untuk mengidentifikasi tugas;

e. mendemonstrasikan suatu kesadaran tentang dimensi nilai dan kesiapan terhadap tantangan asumsi.

2. Perencana,yaitu;
a. kemampuan pencapaian target;
merencanakan
b. kemampuan menilai urutan alternatif strategis sebelum pelaksanaan suatu rencana;

\footnotetext{
${ }^{8}$ Syafaruddin, Manajemen Mutu Terpadu dalam Pendidikan, Jakarta: Grasindo Gramedia, Widia Sarana Indonesia, 2002, h.64-66
}

c. kemampuan menyadari jadwal yang sesuai;

d. kemampuan menentukan prioritas;

e. kemampuan menganalisis elemen penting; dan

f. kemampuan mengembangkan secara detail dan urutan logis rencana untuk mencapai sasaran.

g. Kemampuan berpikir kritis, yang meliputi, kemampuan berpikir analitis dan kritis; kemampuan menerapkan konsep dan prinsip, serta kemampuan membedakan berpikir rutin dan berpikir analitis.

3. Kepemimpinan

a. kemampuan mengarahkan tindakan dari semua orang menuju sasaran yang disepakati;

b. menstrukutur interaksi untuk menjangkau tujuan;

c. memimpin penyebaran secara efektif semua sumber daya;

d. keinginan menerima tanggungjawab untuk tindakan secara bersama dan untuk mencapai tujuan;

e. kemampuan bertindak secara meyakinkan dalam situasi yang sesuai.

4. Kemampuan Mempengaruhi, yaitu:

a. kemampuan untuk memberikan pengaruh atas yang lain dengan tindakan atau keteladanan;

b. kemampuan untuk memperoleh keterlibatan yang lain dalam proses manajemen;

c. membujuk staff untuk menyeimbangkan kebutuhan individual dan kebutuhan organisasi;

d. membujuk personel untuk memperhatikan keluasan berbagai pilihan,

5. Kemampuan Interpersonal, yaitu:

a. kemampuan membangun dan memelihara hubungan positif;

b. kemampuan merasakan kebutuhan, perhatian dan keadaan pribadi dari orang lain; 
c. kemampuan mengenali dan menyelesaikan konflik;

d. kemampuan menggunakan ketrampilan dan mendengarkan secara efektif;

e. kemampuan memberitahukan, menginterpretasikan, merespon perilaku non-verbal;

f. kemampuan menggunakan secara efektif urutan komunikasi lisan dan tulisan;

g. kemampuan memberikan umpan balik yang sesuai dalam suasana yang sensitive.

6. Percaya diri, yaitu:

a. kemampuan untuk merasa yakin akan potensi pribadi dan penilaian;

b. kemampuan mendemonstrasikan prilaku tegas tanpa menggerakkan permusuhan,

c. kemampuan menyusun dan menerima umpan balik dari kinerja seseorang dan gaya manajemen,

d. kemampuan menyampaikan tantangan kepada ornag lain agar menata sikap percaya diri mereka, dan

e. kemampuan menyampaikan umpan balik untuk mengembangkan percaya diri,

7. Empati, yaitu:

a. kemampuan mengungkapkan kesadaran tentang kebutuhan kelompok dan kebutuhan seorang anggota;

b. kemampuan mendengarkan dan berkomunikasi dalam suasana yang konstruktif;

c. kemampuan menyatakan hal yang sensitif untuk mempengaruhi keputusan bagi yang lain,

8. Toleran terhadap stress, yaitu:

a. kemampuan menyatakan perilaku yang sesuai dalam keadaan stress;

b. kemampuan mendemonstrasikan ketabahan/ulet dalam situasi tertekan; c. kemampuan menyisakan secara efektif suatu tingkat pekerjaan;

d. kemampuan memelihara keseimbangan antara beberapa prioritas;

e. kemampuan memperhitungkan tingkatan dari stress orang lain.

Ketrampilan kepala sekolah sebagai pemimpin pendidikan sebagaimana diungkapkan di atas merupakan cakupan yang luas untuk dipenuhi. Oleh karena itu, diperlukan pendidikan, latihan, dan pengalaman untuk memantapkan ketrampilan memimpin dari setiap pimpinan pendidikan termasuk kepala sekolah. Di samping pengetahuan dan pengalaman, maka latihan-latihan kepemimpinan dan manajemen kelembagaan pendidikan termasuk sekolah juga sangat diperlukan. Demikian pula dengan keberhasilan kepala sekolah dalam menjalankan tugasnya adalah dengan mengukur kemampuannya untuk menciptakan iklim pembelajaran yang kondusif. Kegiatannya adalah dengan mempengaruhi, mengajak dan mendorong guru, murid, dan staff sekolah untuk menjalankan tugas masing-masing dengan komitmen yang tinggi.

Terciptanya iklim pembelajaran secara tertib, lancar, dan efektif, tidak terlepas dari kegiatan manajemen mutu yang dilakukan kepala madrasah dalam kapasitasnya sebagai pimpinan di sekolah. Dewasa ini, permasalahan dalan dunia pendidikan begitu kompleks sehingga mutlak keberadaan pemimpin yang berakhlakul karimah merupakan suatu kebutuhan dan keharusan. Apapun aktivitas yang dilakukan oleh pemimpin dan yang dipimpin titik berangkatnya adalah keberadaan akhlak. Sebagai pegangan, beberapa hal yang perlu diperhatikan oleh pemimpin termasuk kepemimpinan pendidikan disampaikan oleh Muhamad Mu'iz Raharjo, bahwa "pimpinan haruslah memastikan dirinya, 
mempunyai akhlak yang baik, yaitu mencakup istiqomah, memelihara diri sendiri, bijaksana, tenang, sabar, hidup sederhana, tidak takabur, adil, jujur, dan tawakal kepada Allah SWT". 9

Agar tujuan pendidikan Islam bisa dicapai sesuai dengan yang diharapkan maka diperlukan adanya manajer/kepemimpinan yang handal yang mampu membuat perencanaan yang baik, mengorganisir, menggerakkan, dan melakukan kontrol serta tahu kekuatan, kelemahan, peluang, dan ancaman, maka orang yang diberi amanat dalam memanaj lembaga pendidikan Islam perlu memiliki kompetensi sesuai dengan tuntunan AlQur'an, yang menurut Tanthowi kompetensi tersebut antara lain:

1) Berpengetahuan luas, kreatif, inisiatif, peka, dan lapang dada. Hal ini sesuai dengan QS al-Mujadalah [58];11,

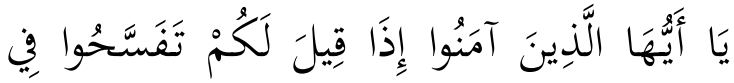
الْمَجَالِسِ فَافْسَحُوا يَفْسَحَح اللهُ لَكُْْ وَإِذَا قِيلَ

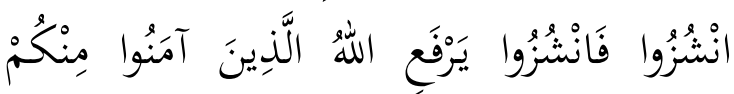

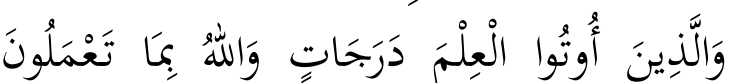

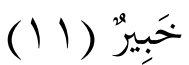

Hai orang-orang beriman apabila kamu dikatakan kepadamu: "Berlapanglapanglah dalam majlis", Maka lapangkanlah niscaya Allah akan memberi kelapangan untukmu. dan apabila dikatakan: "Berdirilah kamu", Maka berdirilah, niscaya Allah akan meninggikan orang-orang yang beriman di antaramu dan orang-orang yang diberi ilmu pengetahuan beberapa derajat. dan Allah Maha mengetahui apa yang kamu kerjakan.

${ }^{9}$ Muhamad Mu'iz Raharjo, Manajemen Sumber Daya Manusia yang Unggul, Cerdas, \& Berkarakter Islami, Yogyakarta: Gava Media, 2011, h. 40-50
2) Bertindak adil dan jujur serta konsekuen. Hal ini sesuai dengan QS alNisa [4]: 58:

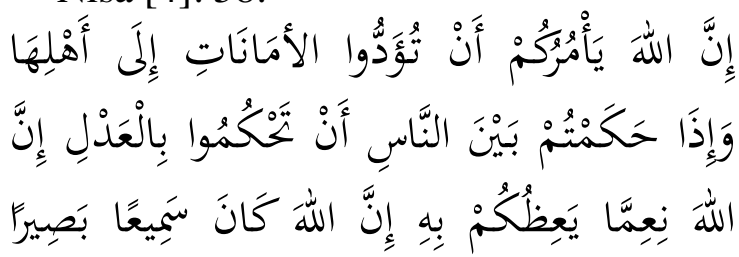

$(0 \wedge)$

Sesungguhnya Allah menyuruh kamu menyampaikan amanat kepada yang berhak menerimanya, dan (menyuruh kamu) apabila menetapkan hukum di antara manusia supaya kamu menetapkan dengan adil. Sesungguhnya Allah memberi pengajaran yang sebaik-baiknya kepadamu. Sesungguhnya Allah adalah Maha mendengar lagi Maha Melihat.

3) Bertanggung Jawab. Sesuai denganQS al-An'am [6]: 164;

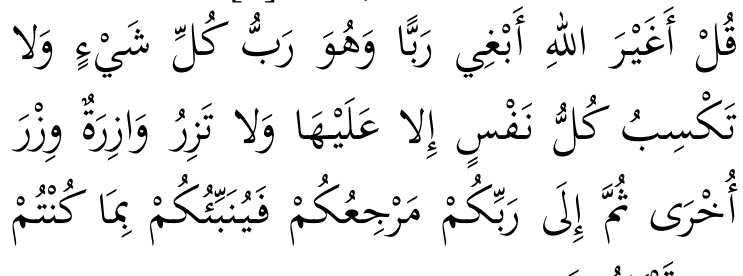

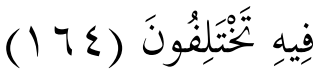

Katakanlah: "Apakah Aku akan mencari Tuhan selain Allah, padahal dia adalah Tuhan bagi segala sesuatu. dan tidaklah seorang membuat dosa melainkan kemudharatannya kembali kepada dirinya sendiri; dan seorang yang berdosa tidak akan memikul dosa orang lain. Kemudian kepada Tuhanmulah kamu kembali, dan akan diberitakan-Nya kepadamu apa yang kamu perselisihkan."

4) Selektif terhadap informasi. Sesuai dengan QS al-Hujurat [49]: 6:

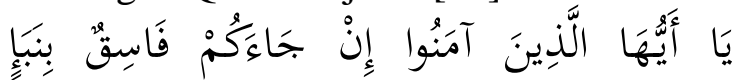

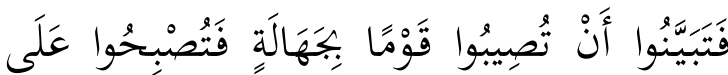

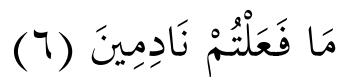

Hai orang-orang yang beriman, jika datang kepadamu orang fasik membawa 
suatu berita, Maka periksalah dengan teliti agar kamu tidak menimpakan suatu musibah kepada suatu kaum tanpa mengetahui keadaannya yang menyebabkan kamu menyesal atas perbuatanmu itu.

5) Memberi Peringatan. Sesuai QS alDzariat [51]: 55

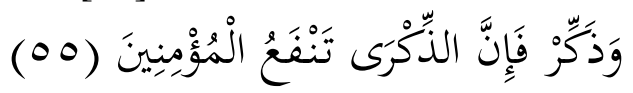

Dan tetaplah memberi peringatan, Karena Sesungguhnya peringatan itu bermanfaat bagi orang-orang yang beriman.

6) Memberi petunjuk dan pengarahan. Sesuai dengan QS al-Sajdah [32]: 24;

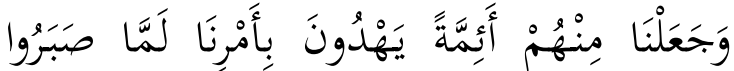

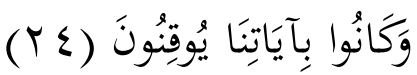

Dan kami jadikan di antara mereka itu pemimpin-pemimpin yang memberi petunjuk dengan perintah kami ketika mereka sabar. dan adalah mereka meyakini ayat-ayat kami.

Selain memiliki kompetensi diatas juga dipelukan memiliki teladan yang menjadi model ideal pemimpin(QS AlAhzab:21), Rasulullah dikaruniai empat sifat utama, yaitu: Sidiq, Amanah, Tablig dan Fathonah. Sidiq berarti jujur dalam perkataan dan perbuatan, amanah berarti dapat dipercaya dalam menjaga tanggung jawab, Tablig berarti menyampaikan segala macam kebaikan kepada rakyatnya dan fathonah berarti cerdas dalam mengelola.

Mengenai empat sifat utama diatas ada yang menarik mengenai nilai amanah, Daniel Goleman mencatat beberapa ciri orang yang memiliki sifat tersebut.

a. Dia bertindak berdasarkan etika dan tidak pernah mempermalukan orang

b. Membangun kepercayaan diri lewat keandalan diri dan autentisitas (kemurnia/kejujuran) c. Berani mengakui kesalahan sendiri dan berani menegur perbuatan tidka etis ornag lain

d. Berpegang kepada prinsip secara teguh, walaupun resikonya tidak disukai serta memiliki komitmen dan menepati janji

e. Bertangung jawab sendiri untuk memperjuangkan tujuan serta terorganisir dan cermat dalam bekerja. (Goleman, 1998). ${ }^{10}$

\section{Kesimpulan}

Islam memberikan dasar-dasar normatif dan filosofis tentang kepemimpinan yang bersifat komprehensip dan universal. Tidak hanya untuk umat Islam tapi juga untuk seluruh umat manusia. Agar tujuan pendidikan Islam bisa dicapai sesuai dengan yang diharapkan maka diperlukan adanya manajer/kepemimpinan yang handal yang mampu membuat perencanaan yang baik, mengorganisir, menggerakkan, dan melakukan kontrol serta tahu kekuatan, kelemahan, peluang, dan ancaman, maka orang yang diberi amanat dalam memanaj lembaga pendidikan Islam perlu memiliki kompetensi sesuai dengan tuntunan AlQur'an, diantaranya: Berpengetahuan luas, kreatif, inisiatif, peka, dan lapang dada QS al-Mujadalah[58];11. Bertindak adil dan jujur serta konsekuen QS al-Nisa [4]: 58:. Bertanggung Jawab QS al-An'am [6]: 164. Selektif terhadap informasi QS al-Hujurat [49]: 6. Memberi Peringatan QS al-Dzariat [51]: 55. Memberi petunjuk dan pengarahan QS al-Sajdah [32]: 24. Kepemimpinan diperlukan memiliki teladan yang menjadi model ideal pemimpin (QS Al-Ahzab: 21), Rasulullah dikaruniai empat sifat utama, yaitu: Sidiq, Amanah, Tablig dan Fathonah. Sidiq berarti jujur dalam perkataan dan perbuatan, amanah berarti dapat dipercaya

\footnotetext{
${ }^{10}$ Toto Tasmara, Spiritual Centered Leadership, h. 124
} 
dalam menjaga tanggung jawab, Tablig berarti menyampaikan segala macam kebaikan kepada rakyatnya dan fathonah berarti cerdas dalam mengelola.

\section{DAFTAR PUSTAKA}

E. Mulyasa. Manajemen Berbasis Sekolah Konsep, Strategi dan Implementasi, (Bandung: Remaja Rosda Karya, 2004)

Hadari Nawawi. Administrasi Pendidikan (Jakarta: CV. Haji Mas Agung 1997)

Muhamad Mu'iz Raharjo, Manajemen Sumber Daya Manusia yang Unggul, Cerdas, \& Berkarakter Islami, (Yogyakarta: Gava Media, 2011).

Sudarwan Danim. Visi Baru Manajemen, (Jakarta: Bumi Aksara, 2005)

Sutopo Hadiyat dan Wasty, Kepemimpinan yang afektif (Yogyakarta: Gajah Mada University 1998)

Syafaruddin, Manajemen Mutu Terpadu dalam Pendidikan, (Jakarta: Grasindo Gramedia, Widia Sarana Indonesia, 2002).

Veithza Rivai, Kiat Memimpin Abad 21, (Jakarta: PT Raja Grafindo, 2004)

Wahjosumidjo. Kepemimpinan Kepala Sekolah, (Jakarta: Grafindo Persada 1999) 
